\title{
Indigenous Study on the Institution of Security Investor Protected Fund
}

\author{
Zhou Jing \\ Jiangxi College Of Foreign Studies
}

\begin{abstract}
With the development of world financial market after the second world war, security market has also been developed rapidly, which has brought prosperous economic development together with increasingly fiercer competition. The competition follows the basic principle of survival of the fittest. Thus, some security companies with weak competitiveness and poor operation have to leave the financial security market finally. Furthermore, if one security company leaves the financial market due to poor competitiveness, its customers' interest will be directly damaged. In the paper, theories of the institution of security investor protected fund are explained, which lays theoretical basis for the localization of security investor protection fund system.

Keywords-security investment; protected fund; corporation finance; finance and banking
\end{abstract}

\section{INTRODUCTION}

With the development of economic globalization, China has paid increasingly more attention to fiance, which has received great development in domestic financial market in recent years. At the same time, security market has also been developed rapidly, during which more and more security companies have been knocked out the market due to fierce competition. Therefore, it is a problem needing to be solved urgently to protect security investors' interest while guaranteeing the effective implementation of "survival of the fittest" competition mechanism.

The institution of security investor protected fund plays a key role in preventing and solving losses of security investors while financial crisis occurs. This

\section{Establishment of Shanghai Stock Exchange after the reform and opening up}

The reform and opening up policy carried out since the 1970s has not only brought revolutions on political and economical systems, but also brought development in security market. In 1986, Jingan Security Business Department of Shanghai Trust and Investment Company by ICBC, the first security company up to stock agency and transference in new China, began to conduct business activities. Since then, security exchange market began to develop vigorously after 30-year interruption.

\section{THEORETICAL BASIS FOR THE INSTITUTION OF SECURITY INVESTOR PROTECTED FUND}

In order to conduct indigenous study on the institution of security investor protected fund, we need to know about the theoretical basis of security investor protected fund system first. In the following contents, the author will conclude the theories and legal regulations in each country. In the paper, a relatively institution is an important part of legal system used to standardize security market as well as one of the main systems guaranteeing the stability of financial market. Thus, study and perfection on the localization of security investor protection fund system is of great significance.

\section{DEVELOPMENT HISTORY OF CHINESE SECURITY INVESTOR PROTECTION FUND SYSTEM}

Development of Chinese security investment market can be divided into three stages

\section{A. Security market before the liberation}

Security market in this period is semi-colonial and semi-feudal. The earliest security trading agencies in China were established by western businessman, which were called Shanghai Shares Company and Shanghai Stock Exchange. The main business is buying and selling stocks from the stock exchanges.

\section{B. From 1949 to 1970 s}

Since the establishment of New China, security market once had an active period. At the early stage of new China, there were also many semi-feudal and semi-colonial security companies, which received rapid development. However, due to the lack of scientific rules and standards, security market in this period mainly developed the economic construction by receiving bureaucratic capitals, so many security exchanges got losses quickly.

scientific definition of security investor protection fund system is concluded, which provides theoretical basis for China.

\section{A. Legal definition of security investor protection fund}

Legal definitions of security investor protection fund system are different in different countries and regions. Before studying the security investor protection fund, we need to understand different legal definitions under different economic environment so as to explore the most suitable definition for our country by exploring their similarities.

\section{B. Analysis on the theories of security investor protection fund system}

It is not enough to study the definition of security investor protection fund prescribed in legislation because theoretical basis for the formulation of security investor protection fund system in each country comes from the theoretical analysis in economic world and legal world. 


\section{Legalfeatures of security investor protection fund system}

Legal features should be seen as the basis to study the theoretical basis of security investor protection fund system. As a legal system of security, security investor protection fund system has its unique legal features, which are insurance of compensation and reliability of fund.

\section{SUGGESTIONS FOR THE LOCALIZATION OF} SECURITY INVESTOR PROTECTION FUND SYSTEM

In order to solve the institutional defects of security investor protection fund system and problems existing in the practice, two suggestions have been proposed by the author by combining overseas advanced legislation experience with Chinese practical security market situations so as to conduct indigenous study on the system.

\section{A. To perfect the institutional system of security investor protection fund system}

First, it is of great necessity to formulate a perfect institutional system for promoting the indigenous study on security investor protection fund. This perfect institutional system should be a basic legislation which is more suitable for China's national conditions and world economic development laws as well as the current development situations of security market; and meanwhile it requires to establish a complete compensation mechanism as well as more standard capital sources.

\section{B. To standardize the functional range of security investor protection fund companies}

In order to make the institution of security investor protection fund better suitable for China's national conditions, besides perfect institutional system, we also need to standardize the functional range of security investor protection fund companies which are served as supervision organs. Especially, the rights of intervention and relief should be defined so as to ensure the effect of security investor protection fund companies in protection investors' interest.

\section{CONCLUSION}

In order to conduct indigenous study on security investor protection fund system, one of the most important points is to know about the current situation of the system in China first, which requires professional market survey as well as rich financial knowledge. Thus, two suggestions have been proposed to perfect the institutional system of security investor protection fund system and standardize the functional ranges of security investor protection fund companies. However, whether the two suggestions can be realized or not needs test of market and time. We should clear about the essential nature of security investor protection fund system, which is a system of compensation and relief. It can't stop the bankrupt risk of security companies fundamentally as well as eliminate the damage of security investors after exiting financial market, but it can help to reduce and compensate these damages as possible as it can.

\section{REFERENCES}

[1] Carré E. The origins of inflation targeting regime: the science of central banking or the art of central bankers?[J]. Cahiers D'économie Politique, 2014:127-172.

[2] Gillian Pascall, Susan Parker, Julia Evetts. Women in Banking Careers - a Science of Muddling Through?[J]. Journal of Gender Studies, 2000, 9(1):63-73.

[3] Pascall G, Parker S, Evetts J. Women in Banking Careers-a Science of Muddling Through?[J]. Journal of Gender Studies, 2000, 9(1):63-73.

[4] Neuberger D. Industrial Organization of Banking: A Review[J]. Social Science Electronic Publishing, 2010, 5(1):97-118.

[5] Rudiger Ahrend, Antoine Goujard. Drivers of Systemic Banking Crises: The Role of Bank-Balance-Sheet Contagion and Financial Account Structure[J]. Social Science Electronic Publishing, 2012.

[6] Berger A N. International Comparisons of Banking Efficiency[J]. Social Science Electronic Publishing, 2007, volume 16(3):119-144(26).

[7] Samolyk K, Avery R B. Bank Consolidation and the Provision of Banking Services: The Case of Small Commercial Loans[J]. Social Science Electronic Publishing, 2000.

[8] Xian S D, Gan Z X, Chen Z J, et al. Study of Individuals Adoption of Internet Banking based on PCA-FCE[J]. Mathematics in Practice \& Theory, 2015.

[9] Calomiris C W, Nissim D. Crisis-Related Shifts in the Market Valuation of Banking Activities[J]. Social Science Electronic Publishing, 2013, 23(3):400-435.

[10] Cohen K J, Weide J H V. RECENT DEVELOPMENTS IN MANAGEMENT SCIENCE IN BANKING[J]. Management Science, 1981, 27(10):1097-1119.

[11] Beck T, Brown M. Use of Banking Services in Emerging Markets - Household-Level Evidence[J]. Social Science Electronic Publishing, 2011.

[12] Haneef S, Riaz T, Ramzan M, et al. Impact of Risk Management on Non-Performing Loans and Profitability of Banking Sector of Pakistan[J]. International Journal of Humanities \& Social Science, 2012. 